\title{
Bio-efficacy and Phytotoxicity of 2, 4-D Dimethyl Amine 50\% SL for Weed Control in Potato and Its Effect on Succeeding Crop Greengram
}

\author{
Utpal Biswas*, Arindam Kundu, Abisekh Labar, Madhab Kumar Datta and \\ Champak Kumar Kundu
}
Department of Agronomy, Faculty of Agriculture, Bidhan Chandra Krishi Viswavidyalaya, Mohanpur, Nadia, West Bengal- 741252, India
*Corresponding author

\section{A B S T R A C T}

\begin{tabular}{|l|}
\hline Ke y w o r d s \\
2, 4-D dimethyl \\
amine, Weed, Potato, \\
Greengram.
\end{tabular}

Keywords

2, 4-D dimethyl

amine, Weed, Potato,

10 November 2017
The experiment was conducted during rabi season of 2014-15 and 2015-16 at Regional Research Station of New Alluvial Zone (NAZ), Gayeshpur of West Bengal to find out the bio-efficacy and phytotoxicity of 2, 4-D dimethyl amine 50\% SL for weed control in potato and its effect on succeeding crop greengram. Elusine indica, Cynodon dactylon, Cyperus rotundus, Cyperus iria, Anagallis arvensis, Chenopodium album and Fumaria parviflora were the dominant weeds. The post emergence application of 2, 4-D amine 50\% SL $4.0 \mathrm{~kg}$ a.i. $\mathrm{ha}^{-1}$ has resulted in effective weed control, recording the least weed density and weed dry weight and there by higher weed control efficiency after hand weeding twice treatment plot. Among the herbicide, maximum grain yield was recorded under 2, 4-D amine 50\% SL $3.0 \mathrm{~kg}$ a.i. ha ${ }^{-1}\left(23.00 \mathrm{t} \mathrm{ha}^{-1}\right)$. The herbicide 2, 4-D amine 50\% SL tested at different doses was found safe to potato and did not cause any residual toxicity to succeeding crop greengram.

\section{Introduction}

Potato (Solanum tuberosum L.) is an important food and vegetable crop of the world and produces more weight and calories per unit area as compared to all other food crops (Das, 1993). The potato is a crop which has always been the 'poor man's friend'. For vegetable purposes it has become one of the most popular crops in this country. Potatoes are an economical food, they provide a source of low cost energy to the human diet. Potatoes are a rich source of starch, vitamins especially $\mathrm{C}$ and $\mathrm{B}_{1}$ and minerals. They contain 20.6 per cent carbohydrates, 2.1 per cent protein, 0.3 per cent fat, 1.1 per cent crude fibre and 0.9 per cent ash (Singh et al., 2013). The area and production of potato in the country during 2015-16 is estimated around 20.63 lakhs ha and 455.69 lakhs MT respectively (Hort. Div., 2016). The major potato growing states are Uttar Pradesh, West Bengal, Punjab, Bihar, Haryana, Madhya Pradesh, Gujarat and Maharashtra. West Bengal ranks second in potato production after Uttar Pradesh, in the country. In West Bengal, it is grown in 0.41 million ha area with the production of 12.02 million tones (Hort. Stat. Div., 2015). There are several constraints in potato production, of which weeds often pose a serious problem. The yield reduction due to weeds in potato is estimated to be as high as 10 to $80 \%$ (Lal and 
Gupta, 1984). However, the weeds prevalent in and around the crop hamper potato cultivation thereby resulting in substantial reduction in yield (Singh et al., 1984). Manual weeding by traditional practice is quite effective but a costly, tedious, time consuming and also causes root injury (Khurana et al., 1993). Hence, chemical weed control appears to hold a great promise in dealing with effective, timely and economic weed suppression. 2, 4-D is an exclusively broad-leaved killer herbicide and has some sedge (Cyperus rotundus/esculentus) killing activity (Das, 2013). 2, 4-D amine salts are usually in liquid form. They have balanced solubility in lipoid and water. The persistence in soil is greater and more absorption/uptake by plant through roots (Das, 2013).

\section{Materials and Methods}

The field experiment was conducted to study the effect of bio-efficacy and phytotoxicity of 2, 4-D dimethyl amine 50\% SL for weed control in potato and its effect on succeeding crop greengram during rabi season of 20142015 and 2015-2016 in the sub-humid and sub-tropical condition of West Bengal. All the experiments were conducted under Bidhan Chandra Krishi Viswavidyalaya in different Research Stations. The experiments were conducted at Regional Research Station of New Alluvial Zone (NAZ), Gayeshpur respectively of West Bengal and the Research Stations are situated at $28^{0} 5.3^{\prime} \mathrm{N}$ latitude and $83^{0} 5.3^{\prime}$ E longitude and the election of $9.75 \mathrm{~m}$ above the mean sea level. The Research stations under Bidhan Chandra Krishi Viswavidyalaya, Mohanpur, Nadia, West Bengal. The experiment was laid out in a randomized block design (RBD), replicated thrice. The comprising eight different weed control treatments viz. four different doses of 2, 4-D amine 50\% SL (Nufarm) applied at 1.0, 2.0, 3.0 and $4.0 \mathrm{~kg}$ a.i. $\mathrm{ha}^{-1}, 2$, 4-D amine $58 \%$ SL (Commercial) at $2.0 \mathrm{~kg}$ a.i. $\mathrm{ha}^{-1}$, metribuzine $70 \% \mathrm{WP}$ at $0.50 \mathrm{~kg}$ a.i. $\mathrm{ha}^{-1}$, hand weeding twice at 20 and 40 DAP and unweeded control. Potato variety 'Kufri Jyoti' was sown in $20 \mathrm{~cm}$ spacing using $20 \mathrm{q}$ seed $\mathrm{ha}^{-1}$ on 29 and 21 November of 2014- 2015 and 2015-2016 respectively. Herbicidal treatments were applied as pre emergence $(02$ DAP) and post emergence (after first irrigation) 30 DAP at their respective doses as per treatments. Spraying was done with the help of knapsack sprayer fitted with a flat fan hooded nozzle with the spray volume of water $5001 \mathrm{ha}^{-1}$. Observations on weeds were recorded at 20, 40 and 60 DAP. An area of $0.25 \mathrm{~m}^{2}$ was selected randomly at two spots by throwing a quadrat of $0.5 \times 0.5 \mathrm{~m}$, weed species were counted from that area and density was expressed in number $\mathrm{m}^{-2}$. The collected weeds were first sun-dried and then kept in an electric oven at $70^{\circ} \mathrm{C}$ till the weight became constant and weed biomass was expressed as $\mathrm{g} \mathrm{m}^{-2}$. After weed dry weight, weed control efficiency was calculated by using the formula given by Patel et al., (1987). Phytotoxic effect of herbicides on crop in terms of yellowing, stunting and necrosis were recorded at 10, 20 and 40 DAHA. At maturity, tubers were harvested from net plot area and yield was expressed on ton per hectare basis. The treatments were allocated randomly to different plots with the help of random number table (Fisher, R. A. 1958) and the data were analysed by ANOVA, and ranked by using the critical differences (CD) at 5\% level.

Succeeding crops of greengram was taken during Summer season of 2015 and 2016 by dividing the plot to find out the residual effects of herbicides 2, 4-D amine 50\% SL, 2, 4-D amine 58\% SL and metribuzine 70\% WP. Greengram variety 'Samrat' was sown in 30 cm spacing using $20 \mathrm{~kg}$ seed ha ${ }^{-1}$ on 23 and 15 March. These studies were continued in fixed lay out without disturbing the soil. The weeds were removed manually in these crops. 


\section{Results and Discussion}

\section{Effect on weeds}

The dominant weed flora of the experimental field during both the years was infested with grasses, viz. Elusine indica, Cynodon dactylon, Dactyloctenium aegyptium sedges viz. Cyperus rotundus, Cyperus iria, and few broad-leaved weeds, viz. Anagallis arvensis, Chenopodium album, Fumaria parviflora.

It was observed that the population of broad leaf weed, grassy weed and sedge varied significantly during both the years due to weed control treatments (Table 1). The population of broad leaf weed $(9.66,7.32$ and 17.50 no. $\mathrm{m}^{-2}$ respectively), grassy weed (6.34, 6.68 and 10.84 respectively) and sedge weed $\left(16.00,13.00\right.$ and 22.66 no. $\mathrm{m}^{-2}$ respectively) populations was lower under hand weeding twice at 20,40 and 60 DAP. Among the herbicides, 2, 4-D amine 50\% SL $4.0 \mathrm{~kg}$ a.i. $\mathrm{ha}^{-1}$ recorded least weed population at 20, 40 and 60 DAP and followed by 2, 4-D amine $50 \%$ SL $3.0 \mathrm{~kg}$ a.i. ha ${ }^{-1}$. The data on weed count has revealed that in 2, 4-D amine $50 \%$ SL $4.0 \mathrm{~kg}$ a.i. $\mathrm{ha}^{-1}$ has resulted in effective control of total weed population and has recorded least weed count $(32.00,27.00$ and 51.00 no. $\mathrm{m}^{-2}$ respectively) at 20,40 and 60 DAP and remained at par among themselves and superior to the other treatments except hand weeding twice.

The treatments, 2, 4-D amine 50\% SL $4.0 \mathrm{~kg}$ a.i. $\mathrm{ha}^{-1}$ was at par with $2,4-\mathrm{D}$ amine $50 \% \mathrm{SL}$ $3.0 \mathrm{~kg}$ a.i. $\mathrm{ha}^{-1}$ in controlling the total weed population. Maximum weed population was recorded under the unweeded control treatment at all the observations with the pre dominance of sedges $(86.00,90.33$ and 94.50 no. $\mathrm{m}^{-2}$ respectively) followed by broadleaf weeds $\left(42.66,51.96\right.$ and 63.33 no. $\mathrm{m}^{-2}$ respectively) and grasses $(32.58,35.21$ and 43.56 no. $\mathrm{m}^{-2}$ respectively).
All the herbicides significantly reduced dry matter production of weeds compared to unweeded control at 20, 40, 60 DAP (Table 2). At 20, 40, 60 DAP, the lowest dry matter production of weeds was recorded in hand weeding twice $\left(10.05,9.20\right.$ and $17.30 \mathrm{~g} \mathrm{~m}^{-2}$ respectively) followed by 2, 4-D amine $50 \%$ SL $4.0 \mathrm{~kg}$ a.i. ha ${ }^{-1}(19.50,23.00$ and $32.85 \mathrm{~g}$ $\mathrm{m}^{-2}$ respectively) and 2, 4-D amine 50\% SL $3.0 \mathrm{~kg}$ a.i. $\mathrm{ha}^{-1}\left(21.00,25.00\right.$ and $34.90 \mathrm{~g} \mathrm{~m}^{-2}$ respectively). Among the herbicides, 2, 4-D amine 50\% SL $4.0 \mathrm{~kg}$ a.i. $\mathrm{ha}^{-1}$ recorded lowest weed dry weight, while Metribuzin 70\% WP $0.50 \mathrm{~kg}$ a.i. $\mathrm{ha}^{-1}$ recorded higher dry matter production of weeds. The weed dry weight in the aforesaid treatments remained at par among themselves and remain significantly superior to the other treatments at all the stages especially that the standard treatments viz., 2, 4 D amine 58\% SL (Commercial) 2.0 $\mathrm{kg}$ a.i. $\mathrm{ha}^{-1}$ and Metribuzin $70 \%$ WP $0.50 \mathrm{~kg}$ a.i. ha ${ }^{-1}$. Among the treatments, maximum dry matter production of weeds was recorded under the unweeded control treatment (56.02, 60.98 and $70.10 \mathrm{~g} \mathrm{~m}^{-2}$ respectively) at all the observations.

The weed control efficiency derived from the weed dry weight revealed, hand weeding twice resulted with the higher weed control efficiency of $82.06,84.91$ and $75.32 \%$ during 20, 40 and 60 DAP respectively (Table 2 ).

This was followed by 2, 4-D amine 50\% SL $4.0 \mathrm{~kg}$ a.i. $\mathrm{ha}^{-1}(65.19,62.28$ and $53.14 \%$ at 20, 40 and 60 DAS respectively) and 2, 4-D amine $50 \%$ SL $3.0 \mathrm{~kg}$ a.i. $\mathrm{ha}^{-1}(62.51,59.00$ and $50.21 \%$ at 20,40 and 60 DAS respectively). The weed control efficiency of the aforesaid treatments remained comparable with each other and better than other treatments. Among the treatments, the lowest weed control efficiency was recorded in Metribuzin 70\% WP $0.50 \mathrm{~kg}$ a.i. $\mathrm{ha}^{-1}$ (53.14, 46.51 and $39.94 \%$ at 20.40 and 60 DAP respectively). 
Table.1 Effect of treatments on density of different weeds $\mathrm{m}^{-2}$ in potato (pooled data of two years)

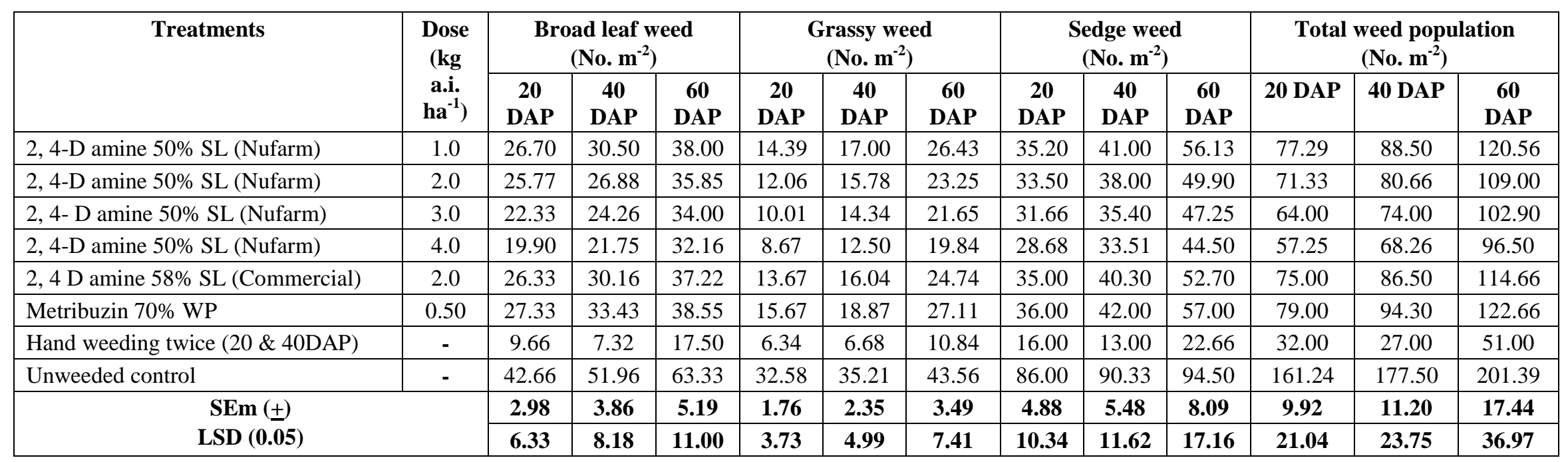

Table.2 Effect of treatments on weed dry matter accumulation, weed control efficiency, phytotoxicity and grain yield of Potato (pooled data of two years)

\begin{tabular}{|c|c|c|c|c|c|c|c|c|c|c|c|}
\hline \multirow[t]{2}{*}{ Treatments } & \multirow{2}{*}{$\begin{array}{c}\text { Dose } \\
(\mathbf{k g} \text { a.i. } \\
\left.\text { ha }^{-1}\right)\end{array}$} & \multicolumn{3}{|c|}{$\begin{array}{c}\text { Total weed dry matter } \\
\text { accumulation }\left(\mathrm{g} \mathrm{m}^{-2}\right)\end{array}$} & \multicolumn{3}{|c|}{$\begin{array}{c}\text { Weed control efficiency } \\
(\%)\end{array}$} & \multicolumn{3}{|c|}{ Phytotoxicity observation } & \multirow[t]{2}{*}{$\begin{array}{l}\text { Tuber yield } \\
\quad\left(\mathrm{t} \mathrm{ha}^{-1}\right)\end{array}$} \\
\hline & & $\begin{array}{c}20 \\
\text { DAP }\end{array}$ & $\begin{array}{c}40 \\
\text { DAP }\end{array}$ & 60 DAP & $\begin{array}{c}20 \\
\text { DAP }\end{array}$ & $\begin{array}{c}40 \\
\text { DAP }\end{array}$ & $\begin{array}{c}\text { 60 } \\
\text { DAP }\end{array}$ & $\begin{array}{c}10 \\
\text { DAHA }\end{array}$ & $\begin{array}{c}20 \\
\text { DAHA }\end{array}$ & $\begin{array}{c}40 \\
\text { DAHA }\end{array}$ & \\
\hline 2, 4-D amine 50\% SL (Nufarm) & 1.0 & 25.36 & 30.05 & 40.21 & 54.73 & 50.72 & 42.64 & 0 & 0 & 0 & 20.10 \\
\hline 2, 4-D amine $50 \%$ SL (Nufarm) & 2.0 & 23.10 & 27.30 & 36.20 & 58.76 & 55.23 & 48.36 & 0 & 0 & 0 & 21.90 \\
\hline 2, 4- D amine 50\% SL (Nufarm) & 3.0 & 21.00 & 25.00 & 34.90 & 62.51 & 59.00 & 50.21 & 0 & 0 & 0 & 23.00 \\
\hline 2, 4-D amine 50\% SL (Nufarm) & 4.0 & 19.50 & 23.00 & 32.85 & 65.19 & 62.28 & 53.14 & 0 & 0 & 0 & 22.80 \\
\hline 2, $4 \mathrm{D}$ amine 58\% SL (Commercial) & 2.0 & 24.80 & 29.00 & 39.45 & 55.73 & 52.44 & 43.72 & 0 & 0 & 0 & 20.00 \\
\hline Metribuzin $70 \% \mathrm{WP}$ & 0.50 & 26.25 & 32.62 & 42.10 & 53.14 & 46.51 & 39.94 & 0 & 0 & 0 & 18.95 \\
\hline Hand weeding twice (20 \& 40DAP) & - & 10.05 & 9.20 & 17.30 & 82.06 & 84.91 & 75.32 & 0 & 0 & 0 & 23.50 \\
\hline Unweeded control & - & 56.02 & 60.98 & 70.10 & - & - & - & 0 & 0 & 0 & 10.55 \\
\hline \multirow{2}{*}{\multicolumn{2}{|c|}{$\begin{array}{c}\text { SEm }( \pm+) \\
\text { LSD }(0.05)\end{array}$}} & 3.31 & 3.82 & 5.95 & - & - & - & - & - & - & 0.56 \\
\hline & & 7.02 & 8.10 & 12.62 & - & - & - & - & - & - & 1.70 \\
\hline
\end{tabular}


Table.3 Residual effect of different herbicides applied in potato on succeeding greengram crop (pooled data of two years)

\begin{tabular}{|c|c|c|c|c|c|}
\hline Treatments & $\begin{array}{c}\text { Dose } \\
(\mathbf{k g} \text { a.i. } \\
\left.\text { ha }^{-1}\right)\end{array}$ & $\begin{array}{c}\text { Germination \% } \\
\text { at } 10 \text { DAS }\end{array}$ & $\begin{array}{l}\text { Plant height }(\mathrm{cm}) \\
\text { at } 40 \text { DAS }\end{array}$ & $\begin{array}{l}\text { Plant dry weight (g } \\
\text { plant }^{-1} \text { ) at } 40 \text { DAS }\end{array}$ & $\underset{1}{\text { Yield }_{\text {(q }} \text { ha }^{-}}$ \\
\hline 2, 4-D amine 50\% SL (Nufarm) & 1.0 & 69.50 & 35.69 & 4.12 & 4.25 \\
\hline 2, 4-D amine 50\% SL (Nufarm) & 2.0 & 73.66 & 36.26 & 4.35 & 4.99 \\
\hline 2, 4- D amine 50\% SL (Nufarm) & 3.0 & 75.00 & 36.92 & 4.70 & 5.85 \\
\hline 2, 4-D amine 50\% SL (Nufarm) & 4.0 & 72.50 & 37.14 & 4.57 & 5.60 \\
\hline $\begin{array}{l}\text { 2, } 4 \mathrm{D} \text { amine } 58 \% \mathrm{SL} \\
\text { (Commercial) }\end{array}$ & 2.0 & 72.00 & 34.20 & 3.91 & 4.68 \\
\hline Metribuzin $70 \% \mathrm{WP}$ & 0.50 & 70.86 & 33.86 & 3.85 & 4.89 \\
\hline Hand weeding twice & - & 75.95 & 37.81 & 4.98 & 6.15 \\
\hline Unweeded control & - & 66.30 & 31.03 & 3.08 & 4.42 \\
\hline SE (d) & & 6.32 & 2.26 & 0.81 & 0.69 \\
\hline $\mathrm{CD}(\mathrm{P}=\mathbf{0 . 0 5})$ & & NS & NS & NS & NS \\
\hline
\end{tabular}




\section{Phytotoxicity}

The observation on visual crop toxicity was done on 10, 20 and 40 days after herbicide application (Table 2). The visual crop toxicity symptoms like leaf injury, vein clearing, epinasty, hyponasty, scorching and necrosis were observed. There were no crop Phytotoxicity symptoms among the different treatments as well as at the highest dose of 2, 4-D amine 50\% SL $4.0 \mathrm{~kg}$ a.i. $\mathrm{ha}^{-1}$ which indicated that the herbicide was safe for potato.

\section{Effect on crops}

Tuber yield (Table 2) was significantly higher in hand weeding twice $\left(23.50 \mathrm{t} \mathrm{ha}^{-1}\right)$ which was at par with 2, 4- D amine 50\% SL $3.0 \mathrm{~kg}$ a.i. ha ${ }^{-1}\left(23.00 \mathrm{t} \mathrm{ha}^{-1}\right)$ and followed by 2, 4-D amine 50\% SL $4.0 \mathrm{~kg}$ a.i. $\mathrm{ha}^{-1}\left(22.80 \mathrm{t} \mathrm{ha}^{-1}\right)$. Among the herbicides, the lowest grain yield was observed in Metribuzin 70\% WP $0.50 \mathrm{~kg}$ a.i. $\mathrm{ha}^{-1}\left(18.95 \mathrm{t} \mathrm{ha}^{-1}\right)$ followed by 2, 4-D amine 58\% SL $2.0 \mathrm{~kg}$ a.i. ha ${ }^{-1}\left(20.00 \mathrm{t} \mathrm{ha}^{-1}\right)$. The higher tuber yield in hand weeding twice and 2, 4- D amine 50\% SL $3.0 \mathrm{~kg}$ a.i. ha ${ }^{-1}$ treatments was attributed to lower weed population and dry matter production and higher weed control efficiency. These results are similar to the findings of Singh et al., (2007).

\section{Residual effect of herbicides on succeeding crop Greengram}

During both the years, germination percentage, plant height $(\mathrm{cm})$, plant dry weight $\left(\mathrm{g}\right.$ plant $\left.{ }^{-1}\right)$ and yield $\left(\mathrm{q} \mathrm{ha}^{-1}\right)$ of greengram did not vary significantly due to the residual effect of herbicides applied in potato (Table 3 ). The results revealed that the germination percent of succeeding crop at 10 DAS remain slightly affected irrespective of the treatments. This suggests that best germination obtained in hand weeding twice plot $(75.95 \%)$ followed by 2, 4- D amine $50 \%$ SL $3.0 \mathrm{~kg}$ a.i. ha ${ }^{-1}$ plot $(75.00 \%)$.

The higher plant height was observed in hand weeding twice plot $(37.81 \mathrm{~cm})$ at 40 DAS. Among the herbicide, maximum plant height was recorded under 2, 4-D amine 50\% SL 4.0 $\mathrm{kg}$ a.i. $\mathrm{ha}^{-1}$ and followed by 2, 4- D amine $50 \%$ SL $3.0 \mathrm{~kg}$ a.i. $\mathrm{ha}^{-1}\left(23.00 \mathrm{t} \mathrm{ha}^{-1}\right)$. The results revealed that the higher plant dry weight of succeeding crop greengram in hand weeding twice plot $\left(4.98 \mathrm{~g} \mathrm{plant}^{-1}\right)$ and lower plant dry weight obtained in unweeded control plot (3.08 $\left.\mathrm{g} \mathrm{plant}^{-1}\right)$ at 40 DAS.

Yield of succeeding crop green gram showed no distinct variation due to the application of different herbicides at varying doses in every experiment for controlling weeds in potato. Among the herbicides, maximum yield was found in 2, 4- D amine 50\% SL $3.0 \mathrm{~kg}$ a.i. $\mathrm{ha}^{-1}$ $\left(5.85 \mathrm{q} \mathrm{ha}^{-1}\right)$ and followed by 2, 4-D amine $50 \%$ SL $4.0 \mathrm{~kg}$ a.i. ha ${ }^{-1}\left(5.60 \mathrm{q} \mathrm{ha}^{-1}\right)$ and lowest yield was recorded under 2, 4-D amine $50 \%$ SL $1.0 \mathrm{~kg}$ a.i. ha ${ }^{-1}\left(4.25 \mathrm{q} \mathrm{ha}^{-1}\right)$.

From the above study, it is inferred that the herbicide 2, 4-D amine 50\% SL $4.0 \mathrm{~kg}$ a.i. $\mathrm{ha}^{-1}$ has resulted in effective weed control, recording the least weed density and weed dry weight and there by higher weed control efficiency after hand weeding twice treatment plot. In case of yield, 2, 4-D amine 50\% SL $3.0 \mathrm{~kg}$ a.i. ha ${ }^{-1}$ resulted better yield after hand weeding twice plot which was on par with aforesaid treatments. The herbicide 2, 4-D amine 50\% SL tested at different doses for Phytotoxicity has revealed that there is no Phytotoxicity symptoms observed in any of the doses and the tested formulation is safe to the potato crop.

The effect of 2, 4- D amine 50\% SL $3.0 \mathrm{~kg}$ a.i. $\mathrm{ha}^{-1}$ applied in potato during 2014 and 2015 on the succeeding crop revealed that there is harmful effect on germination (\%), 
plant height $(\mathrm{cm})$, plant dry weight $\left(\mathrm{g} \mathrm{plant}^{-1}\right)$ and yield of greengram crop compare to the other herbicidal doses grown during summer season of 2015 and 2016. Hence it can be concluded that the aforesaid treatment of this experiment applied in potato during 2014-15 and 2015-16 is safe for succeeding crop greengram.

\section{Acknowledgement}

Technical grade i.e. 2, 4-D amine 50\% SL provided by $\mathrm{M} / \mathrm{S}$. Mahamaya Life sciences Pvt. Ltd., Gurgaon for financial assistance for coordinating the research activities.

\section{References}

Das, F. C. 1993. Vegetable Crops of India. Kalyani Publishers, Ludhiana. pp. 5878.

Das, T. K. 2013. Weed science basics and applications. Jain Brothers. New Delhi, pp. 381.

Fisher, R A. 1958. Statistical Methods for Research workers. Oliver \& Boyd, Edinburg, London.

Horticulture Division. 2016. Ministry of Agriculture, Government of India, New Delhi, $2^{\text {nd }}$ Advance estimate of Govt. of India.

Horticulture Statistics Division. 2015.
Department of Agriculture, Cooperation and Farmers Welfare. 3rd Advance Estimate.

Khurana, S. C., K. K. Thakral and K. K. Bhatia, 1993. Effect of pendimethalin and isoproturon on weeds and tuber yield of potato. Ind. Potato Assoc. 20: 255-257.

Lal, S. S. and A. Gupta, 1984. Efficacy of different herbicides for controlling weeds in potato. Abstracts of Papers of Annual Conference of Indian Society of Weed Science, BHU, Varansi, p. 36.

Patel, C. J., B. R. Raghavani, V. D. Khanapara, D. H. Khavani and D. D. Malavia, 1987. Comparative efficacy of herbicides for weed control in onion. Ind. Journal Weed Sci. 19: 66-70.

Singh, C., Singh, P. and Singh, R. 2013. Modern Techniques of Raising Field Crops. Oxford \& IBH publishing Co. Pvt. Ltd. New Delhi. pp. 501.

Singh, Govindra, V. M. Bhan, S. S. Tripathi and D. Singh, 1984. Comparative efficacy of herbicides in potato. Ind. Journal Weed Sci. 16: 1-5.

Singh, M., Prabhukumar, S., Sairam, C. V. and Hanji, M. B. 2007. Evaluation of Different Herbicides for Weed Control in Potato. Indian Journal Weed Sci. 39 (3 \& 4): 223-226.

\section{How to cite this article:}

Utpal Biswas, Arindam Kundu, Abisekh Labar, Madhab Kumar Datta and Champak Kumar Kundu. 2017. Bio-efficacy and Phytotoxicity of 2, 4-D Dimethyl Amine 50\% SL for Weed Control in Potato and Its Effect on Succeeding Crop Greengram. Int.J.Curr.Microbiol.App.Sci. 6(11): 1261-1267. doi: https://doi.org/10.20546/ijcmas.2017.611.150 